\title{
Reengineering methodologies
}

Xin, WANG

The Bucharest University of Economic Studies, Faculty of Management, Piata Romana, no. 6, Bucharest, Romania, echo_wang88@yahoo.com

\section{Abstract}

In this paper I try to make a brief presentation of the concept of reengineering expressed in the literature. In the second part of this paper I will try to list the stages of the reengineering methodology and to develop them succinctly.

At the end of the paper I will attach a case study on reengineering and conclusions on this topic.

Keywords: Reengineering, methodologies, company, concept.

JEL Classification: B4, L20.

\section{Introduction}

The concept of reengineering began to be known in the 1990s, this notion being used to make business more efficient. Reengineering has revolutionized managerial theory and practice at the company level by focusing on fundamental, spectacular, profound and radical redesigning and redesigning of work processes and, in particular, those generating added value. ${ }^{1}$

In other words, we can state that the process of reengineering aims to redesign the activity of a company in order to achieve the best results.

${ }^{1}$ I. Verboncu, Reproiectarea manageriala a organizatiei. Teorie. Metodologie. Aplicatii, ed. Printech, Bucuresti, 2013, pg. 26. 
The aim of reengineering is to optimize the development of all the processes involved in the company's activity, to maximize the results with optimal consumption of resources. ${ }^{2}$

The causes that can cause a company to appeal to the process of reengineering are numerous. Among these we can mention: a poor financial activity of the firm, a low market share, too much competition in a field of activity, etc.

In the literature, the concept of reengineering appears for the first time in the book "Reengineering the corporation: a manifest for business revolution" written by Hammer and Champy in 1993, although in the literature this concept has existed since the years 90 , but under other names.

The definition of Hammer and Champy's concept of reengineering is at the heart of the development of numerous managerial processes to redesign a company's business.

In management in Romania, this concept has not been met until the quality management system has been promoted. The key notion that relies on this novel way of change is the "process" to which, we must admit, the Romanian management has little to refer to the emergence and promotion of quality management systems. ${ }^{3}$

\section{Reengineering methodology}

The reengineering methodology involves several steps:

- planning and launching the project;

- analysis of the company's current situation;

- developing the solution;

- study of the previously developed solution;

- developing the solution;

- implementation;

- continuous development. ${ }^{4}$

In order for the reengineering methodology to yield the results and the results to be expected, it is necessary to support the management of the

\footnotetext{
${ }^{2}$ www.prosci.com "Business process reengineering"

3 I. Verboncu, Reproiectarea manageriala a organizatiei. Teorie. Metodologie. Aplicatii, ed. Printech, Bucuresti, 2013, pg. 26.

${ }^{4}$ http://www.creeaza.com/referate/management/Reengineering729.php\#_ftn1
} 
company's top level. This is due precisely to the situation that will arise from reengineering, the purpose of which is to streamline the performance of all the activities of the company in question.

When resorting to such a procedure, we must bear in mind that it represents a consumption of both financial and human resources, and not only, which limits the success of the reengineering procedure to failure.

The concept of reengineering is attractive to managers because it promises short-term economic and financial successes and major increases in company performance; is simple to understand and applied; is presented and promoted as a better alternative to other management concepts, is considered to be less expensive and the benefits are more consistent and short-term; the use of information technology tools will ensure the company's long-term competitiveness and will help it to carry out its work more efficiently. ${ }^{5}$

As you can see, reengineering is not necessary, it is even mandatory for companies that want to adapt and continue to evolve in the current market environment. Old forms of thinking, organization and leadership in production and service provision are not only out of date but must be eradicated.

Calling on such a process does not only bring about changes in the technological processes of a company, but also in human resources (such as employee behavior, etc.). However, at the time when other restructuring strategies were tried to save the company and the bankruptcy was one step, I urge the company's managers to resort to reengineering.

In China, according to some studies carried out, the implementation of the reengineering process shows that this process has a success rate of $71.8 \%$, but Chinese companies do not yet know all the advantages and details of reengineering.

\section{Case study ${ }^{6}$}

Sony and Panasonic are being restructured due to continued TV losses. Two of the most popular brands in the electronics market, especially those for the TVs, Sony and Panasonic, have had hard times ahead of the competitive environment today. The exchange rates of Japanese Yen's disadvantages and the

\footnotetext{
${ }^{5}$ http://www.creeaza.com/referate/management/Reengineering729.php\#_ftn1

${ }^{6}$ http://hometheater.about.com/b/2011/11/02/sony-and-panasonic-restructuring-in-face-ofcontinuing-losses-in-tv-divisions.htm
} 
effects of the tsunami and tsunami crisis the earthquake in Japan. Although both companies have tried to adjust, the changes made so far have not been fruitful.

So Sony and Panasonic are affected by structural changes. For Sony, dividing the TV division into three new divisions: LCD TV's, Outsourcing operations and The New Generation TV's. In addition, Sony has a 50\% share in collaborating with Samsung, which is one of Sony's biggest competitors. On the other hand, the hope for Panasonic is to find a solution to its financial problems in the TV division. This solution would eliminate competition between Panasonic and Sanyo.

The reason why Sanyo's acquisition was important to Panasonic due to the opportunities it offers to develop energy-saving technology with which Panasonic hoped to make a profit by offsetting losses in the TV division.

Looking at these two companies, it is surprising that the two companies are not doing well present in the TV division, taking into account the history of the achievements that both have in the back in this domain. In particular, Panasonic has been the main developer of plasma TV technology and only a few companies have remained plasma-producing, including LG and Samsung (the largest competitors other than Sony). The only advantage for Panasonic is that TVs with plasma technology are clearly superior to those of LCD technology.

\section{Conclusions}

Reengineering seems to be the saving solution of today that can make a major and effective change. New leaders can no longer resort to momentary maneuvers or short-term maneuvers proposed as alternative solutions.

Past experience become irrelevant, and that is why attention must be focused on today's people, people who can bring new ideas and innovative solutions that do not have to go through all the decision-making and operational departments.

Organizations must implement certain tactics to ensure sustainability and long-term profitability. This can be done through plans, objectives and planning that will lead to the achievement of the proposed results and the improvement of the structural organization.

According to the above, we can conclude that the definition of Hammer and Champy's concept of reengineering was the basis for the development of other versions of methodology. A company that uses the reengineering method will always try to implement those strategies to solve the problems it faces. 
The finalization of any methodological variation is the same: the considerable improvement of some managerial and economic-financial performance indicators, in the context of obtaining a competitive advantage. ${ }^{7}$

My opinion is that, depending on the problems faced by an organization, the process of reengineering needs to be dealt with differently, on a case-by-case basis.

Reengineering can bring important benefits to companies even if they are a major and complex change process. In other words, we can state that this phenomenon is a redesign of the company's object of activity in order to obtain optimal results.

A successful company has to come up with something new on the market to meet the needs of its customers. The relationship thus formed, between the company and the clients, must be a permanent one and be in step with the needs of the clients.

Last but not least, reengineering is not the last step in "reviving" a company. Once the redesign process has been completed, the new processes must be conducted in such a way as to achieve higher levels of performance.

Also, a company that has reengineered and succeeded, it is possible that over a certain period of time, if an economic situation requires it, or if major competitors create new products and services, turn to this method again, so that the company he manages is on a permanent ascent.

In conclusion, reengineering means abandoning old methods of addressing problems and finding new solutions starting from scratch. It is not based on making small improvements, but building new ways to have productive activity. It aims at profound transformations in terms of costs, service quality and added value.

7 I. Verboncu, Reproiectarea manageriala a organizatiei. Teorie. Metodologie. Aplicatii, ed. Printech, Bucuresti, 2013, pg. 30. 


\section{References}

[1] Verboncu, Reproiectarea manageriala a organizatiei. Teorie. Metodologie. Aplicatii, ed. Printech, Bucuresti, 2013

[2] www.prosci.com "Business process reengineering"

[3] http://www.creeaza.com/referate/management/Reengineering729.php\#_ftn1

[4] http://hometheater.about.com/b/2011/11/02/sony-and-panasonic-restructuring-in-faceof-continuing-losses-in-tv-divisions.htm 